\title{
Analysis and Future Market Forecast Research of China's End- of-life New Energy Vehicle Recycling and Dismantling Technology
}

\author{
Wang Jia ${ }^{1, *}$, Li Yuke ${ }^{1}$, Pan Wei ${ }^{1}$ and Li Zhenbiao ${ }^{1}$ \\ ${ }^{1}$ China Automotive Technology \& Research Center Co., Ltd. (CATARC)
}

\begin{abstract}
With the rapid increase in the promotion and application volume of new energy vehicles in China, the number of end-of-life new energy vehicles will increase rapidly in the future. Moreover, it brings difficulties to the dismantling of new energy vehicles because of the flammability and explosiveness characteristics of the power battery in new energy vehicles. This paper analyzes the dismantling technology of end-of-life new energy vehicles in China and abroad, and forecasts the inventory of new energy vehicles and the number of end-of-life new energy vehicle in the future, which has important reference significance for the future development of China's industry. Finally, the paper puts forward suggestions to promote the development of the industry.
\end{abstract}

\section{Overview}

In 2019, the production and sales of China's new energy vehicles have reached 1.242 million and 1.206 million respectively, the inventory has reached 3.81 million vehicles, accounting for $1.46 \%$ of the total number of vehicles. In recent years, the inventory of China's new energy vehicles is increasing rapidly. Compared with the traditional vehicle, the power battery of end-of-life new energy vehicle is characterized by being flammable and explosive, so the equipment and technical process used in the process of dismantling are different from the traditional vehicle. China and some countries have carried out the dismantling work of the end-of-life new energy vehicles, and gained some experience. The new energy vehicles popularized and applied in the early stage of our country have entered the scrapping period, and will enter the stage of scale scrapping in the next 2-3 years.

\section{Current situation of recycling and dismantling technology of China's end- of-life new energy vehicles}

\subsection{The key point of the dismantling of the end- of-life new energy vehicle is the dismantling of the power battery}

Compared with the traditional fuel vehicles, the new energy vehicles are quite different in body structure and power source. The traditional fuel vehicles are mainly composed of five assemblies, while the new energy vehicles are mainly composed of power batteries, motors, electric controls, etc.

The total rated voltage of the power battery is 100 $750 \mathrm{~V}$. At present, the total rated voltage of the common power battery on the market is about $384 \mathrm{~V}$. For example, the rated voltage of the cell made of lithium-ion ferrous phosphate positive material is $3.7 \mathrm{~V}$, and the discharge cutoff voltage is $2.5 \mathrm{~V}$. Even when the SOC of the power battery is 0 , the total voltage of the power battery is still as high as $259 \mathrm{~V}$. Under such high voltage, if it is disassembled, packed and transported in an improper way, it is not only easy to cause electric shock casualties, but also once a short circuit occurs, the instantaneous current reaches more than $100 \mathrm{~A}$, resulting in the release of a lot of heat and the sharp temperature rise, and it is very easy to cause fire or even explosion. On the other hand, after long-term use, the safety, stability and other properties of waste power battery are far inferior to those of new battery. Therefore, when dealing with the end-oflife new energy vehicle, especially the power battery, it is necessary to strictly abide by the operating procedures, otherwise it is very likely to cause fire and explosion $\operatorname{hazards}^{[1,2]}$.

At present, most of electric vehicles use lithium-ion batteries as power batteries. Lithium ion batteries contain heavy metals such as copper, cobalt, nickel and manganese, as well as lithium hexafluorophosphate (LiPF6), organic carbonate, refractory organic solvents, etc.. Cobalt, nickel, copper and other heavy metals have a cumulative effect in the environment, which will enter the soil and groundwater through the biological chain, eventually harming human health, with great harm ${ }^{[4]}$. In addition, the components of end-of-life power battery are complex, which will produce a lot of secondary pollution problems in the process of recycling and treatment, and it

\footnotetext{
*Corresponding author: wangjia@catarc.ac.cn
} 
has a certain degree of danger. In addition, improper disassembly method leads to harmful coolant leakage, which causes serious pollution to the air, water and soil, and damages the health of disassembly personnel.

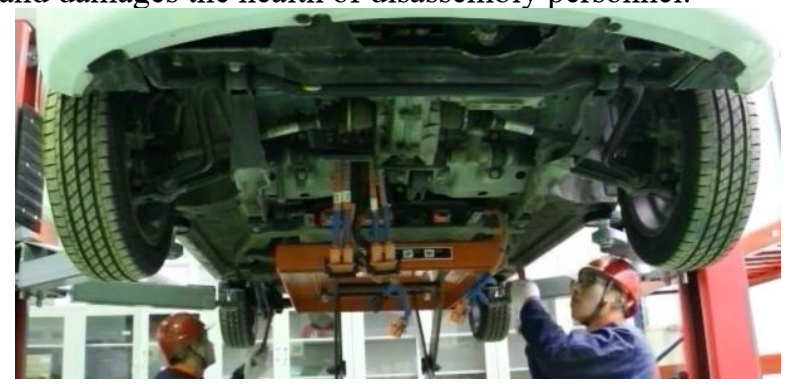

Figure.1. Disassembly of power battery

\subsection{China has considered the technical requirements for the dismantling of new energy vehicles in the formulation of relevant standards}

Due to the great difference between the dismantling of the end-of-life new energy vehicles and the dismantling of the traditional fuel vehicles, the technical differences in the dismantling process of the two types of vehicles are compared in the revised edition of GB22128, and the specific technical requirements for the dismantling process of the end-of-life new energy vehicles are put forward, including the site, personnel, facilities and equipment, safety protection, dismantling process, etc., and the specific dismantling procedures and relevant equipment examples are shown in the table below.

Table.1. Use example of relevant equipment in dismantling procedure ${ }^{[3]}$

\begin{tabular}{|c|c|c|}
\hline \multicolumn{2}{|r|}{ Dismantling procedure } & Dismantling equipment \\
\hline \multirow{6}{*}{$\begin{array}{l}\text { Power battery } \\
\text { dismantling } \\
\text { pre-treatment }\end{array}$} & $\begin{array}{c}\text { Check whether the vehicle body has liquid leakage or is } \\
\text { electrified. }\end{array}$ & Insulation testing equipment, etc. \\
\hline & $\begin{array}{l}\text { Check the layout and installation position of the power battery, } \\
\text { and confirm whether the diagnosis interface is intact }\end{array}$ & $\begin{array}{l}\text { Safety protection and rescue equipment } \\
\text { such as insulating arc protective clothing }\end{array}$ \\
\hline & $\begin{array}{l}\text { Test the voltage, temperature and other parameters of the } \\
\text { power battery to evaluate its safety status }\end{array}$ & $\begin{array}{l}\text { Insulation detection equipment, temperature } \\
\text { detector, etc. }\end{array}$ \\
\hline & Disconnect the high voltage circuit of the power battery & $\begin{array}{l}\text { Power off valve, locking rod, fuse, special } \\
\text { test adapter, high voltage insulating rod, etc. }\end{array}$ \\
\hline & $\begin{array}{l}\text { Use anti-static tools to empty the waste liquid left in the } \\
\text { vehicle on the dismantling pre-treatment platform indoor or } \\
\text { with rain-proof ceiling, and use special containers for } \\
\text { classified recycling }\end{array}$ & $\begin{array}{l}\text { Antistatic insulated vacuum pumping unit, } \\
\text { oil storage container, etc. }\end{array}$ \\
\hline & $\begin{array}{l}\text { Anti-static equipment is used to recycle air conditioning } \\
\text { refrigerant of electric vehicle }\end{array}$ & $\begin{array}{l}\text { Antistatic plastic interface refrigerant } \\
\text { recycling machine, steel cylinder, etc. }\end{array}$ \\
\hline \multirow{5}{*}{$\begin{array}{l}\text { Disassembly } \\
\text { of power } \\
\text { storage battery }\end{array}$} & $\begin{array}{l}\text { Disassemble the power battery barrier components, such as } \\
\text { engine hood, trunk lid, door, etc.. }\end{array}$ & Insulated pneumatic wrench, etc. \\
\hline & $\begin{array}{l}\text { Disconnect the voltage harness (cable) and disassemble the } \\
\text { power battery at different positions }\end{array}$ & $\begin{array}{l}\text { Insulated pneumatic wrench, insulated } \\
\text { shear, insulating material, insulated sling, } \\
\text { clamp arm, manipulator and lifting tooling } \\
\text { equipment, insulated pneumatic wrench, } \\
\text { etc. }\end{array}$ \\
\hline & $\begin{array}{l}\text { Collect the coolant in the power battery pack (set) with liquid } \\
\text { cooling structure }\end{array}$ & $\begin{array}{l}\text { Special insulated callipers, waste liquid } \\
\text { collection devices, etc. }\end{array}$ \\
\hline & $\begin{array}{c}\text { Insulating treatment is carried out for the removed power } \\
\text { battery harness connector, positive and negative pole pieces } \\
\text { and other exposed harnesses and metal objects, and they shall } \\
\text { be labelled on their obvious positions to indicate the insulation } \\
\text { status }\end{array}$ & $\begin{array}{c}\text { Insulation treatment materials, insulation } \\
\text { detection equipment, temperature detector, } \\
\text { etc. }\end{array}$ \\
\hline & $\begin{array}{l}\text { Remove the drive motor after collecting the residual coolant in } \\
\text { the drive motor assembly }\end{array}$ & $\begin{array}{l}\text { Pneumatic tools, motor vehicle lifting } \\
\text { platform, sling, waste liquid collection } \\
\text { device, etc. }\end{array}$ \\
\hline
\end{tabular}

\section{Foreign experience}

\subsection{The electrification transformation of global automobile industry is the basis of realizing the large-scale recycling of new energy vehicles}

According to the statistics of Global EV Outlook 2019 released by the International Energy Agency (IEA), the inventory of global new energy vehicles in 2018 exceeds 5.1 million, with an increase of 2 million over the previous year. China is the world's largest new energy vehicle market, and Europe and the United States rank second and third respectively. Norway has the highest proportion of new energy vehicles in the market promotion and application (46\%). 


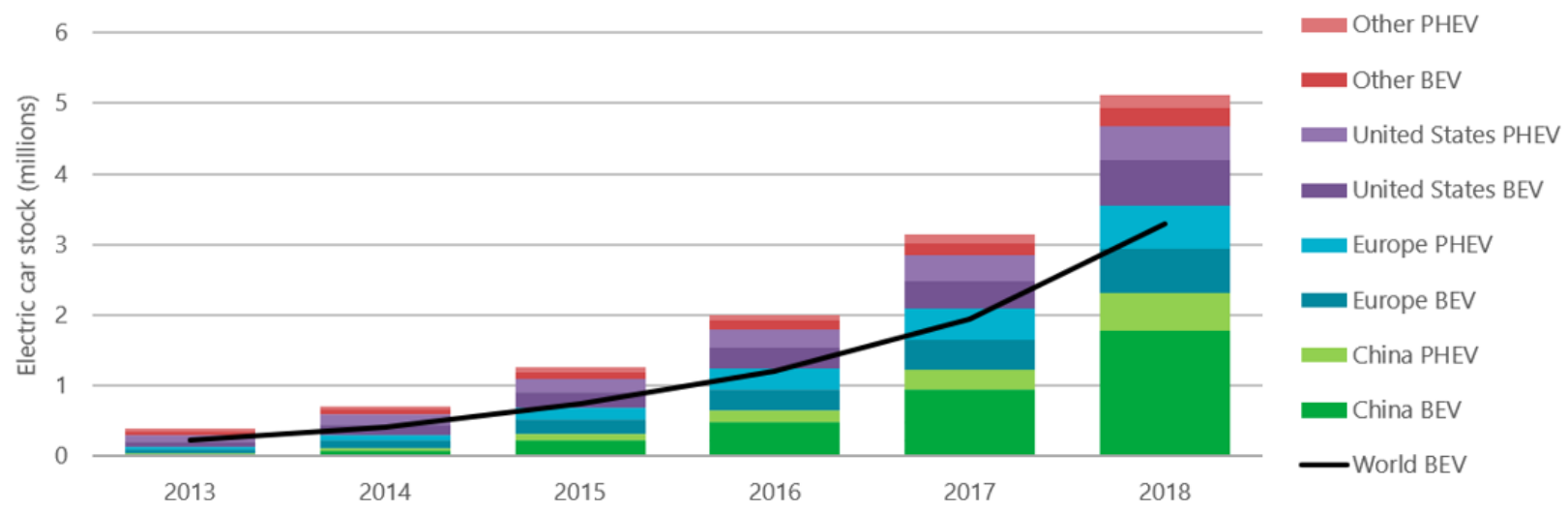

Figure.2. Market segments of global new energy vehicle inventory from 2013 to 2018 Remarks: BEV - battery electric vehicle PHEV -plug-in hybrid electric vehicle Data source: Global EV Outlook 2019 by IEA.

IEA forecasts the future market development of global new energy vehicles according to the two scenarios of new policies (based on the policies and measures already formulated by governments around the world, and the forecast scheme of the possible impact of governments on industrial development) and EV30@30 (in line with the goal committed in EV30@30 Campaign Declaration of new energy vehicle alliance countries, that is, by 2030, the electrification proportion of light-duty vehicles, buses and trucks in the world will reach $30 \%$ ). In the new policy scenario, the sales volume of global new energy vehicles may reach 23 million in 2030, and the inventory may exceed more than 130 million (excluding two / three wheelers); In the EV30@30 scenario, by 2030, the sales volume of new energy vehicles will reach 43 million, and the inventory will exceed 250 million. China, Europe, the United States, Japan and India will be the main new energy vehicle use areas ${ }^{1}$.

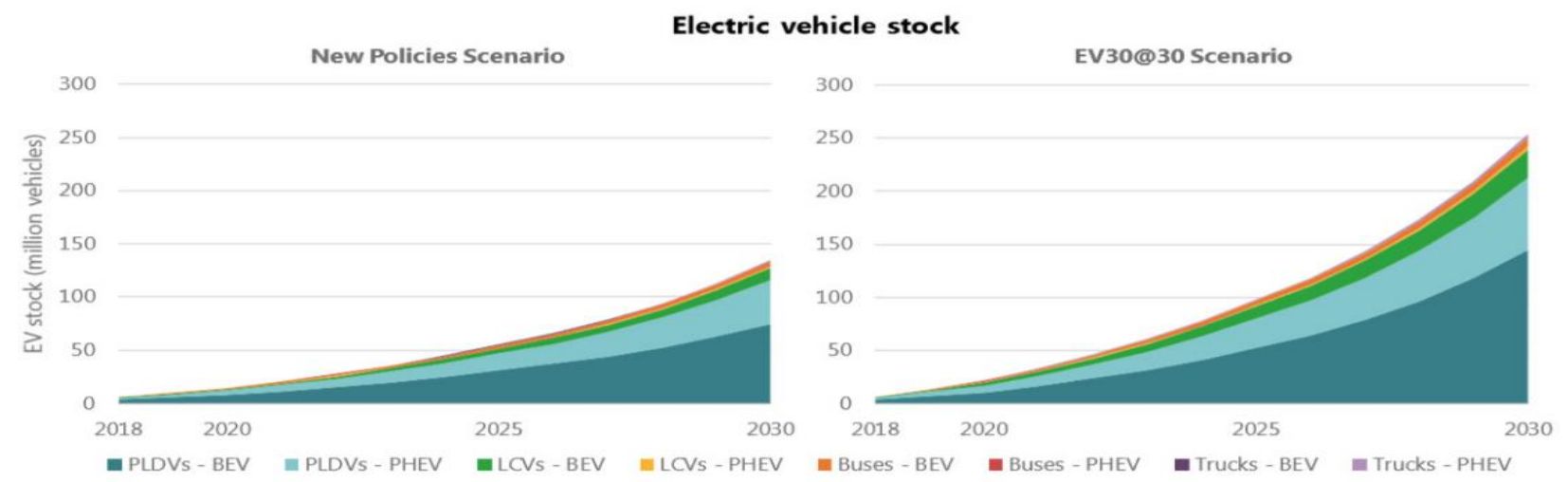

Figure.3. Market segments of global electric vehicle inventory by 2030 Remarks: PLDVs- passenger light duty vehicles; LCVs- light commercial vehicles; BEVs- battery electric vehicles; PHEVs-plug-in hybrid electric vehicles Data source: Global EV Outlook 2019 by IEA.

The electrification transformation and development of global vehicle will continue to drive the use scale of new energy vehicles to rise. In the whole life cycle of the product, the corresponding retired new energy vehicles end-of-life new energy vehicle corresponding to the inventory scale will be generated by decommissioning accordingly. It can be predicted that the recycling scale of global new energy vehicles in the future will continue to increase with the growth of inventory.

\subsection{Foreign countries have begun to build a vehicle power battery recycling system.}

For the entrusted recycling mode of the third-party organization, taking Japan Auto Recycling Partnership (JARP) as an example, the organization is a system established by Japan Automobile Manufacturers Association to collect lithium-ion batteries (hereinafter referred to as $\mathrm{LiB}$ ) for vehicles, which started operation in October 2018, supporting all participants to carry out the recycling business of waste power battery packs

${ }^{1}$ Only BEV and PHEV are included 
nationwide free of charge. At present, JARP has been entrusted by 10 automobile manufacturers, including Toyota and Nissan, to recycle their waste power batteries. In this system, JARP plays an intermediate hub role of information liaison, and its main purpose is to assist vehicle manufacturers in recycling waste power batteries. The operation process is mainly as follows: The dismantling unit (4S shop, maintenance shop, automobile dismantling factory, etc.) of the waste power battery is registered in the system. If there is a battery that needs to be transported, JARP will send the request processing information to JARP. JARP will deliver the packaged power battery pack to the resource-based processing enterprise free of charge according to the demand information.

\subsection{Developed countries such as Europe, the United State and Japan have strictly implemented the extended producer responsibility system}

Developed countries such as Europe, the United States and Japan have strictly implemented the extended producer responsibility system, requiring producers to provide dismantling manuals for their produced models to guide dismantling enterprises to disassemble end-of-life vehicles. For new energy vehicles, manufacturers also provide detailed dismantling information, and make it public on their own websites. In the dismantling manual of new energy vehicles produced by foreign large-scale automobile manufacturers, safety protection and dismantling equipment are required, for example, insulating gloves, safety shoes, goggles and inspection tools are required to be used, and the power battery shall not be dismantled after disassembly, and the battery shall be labelled.

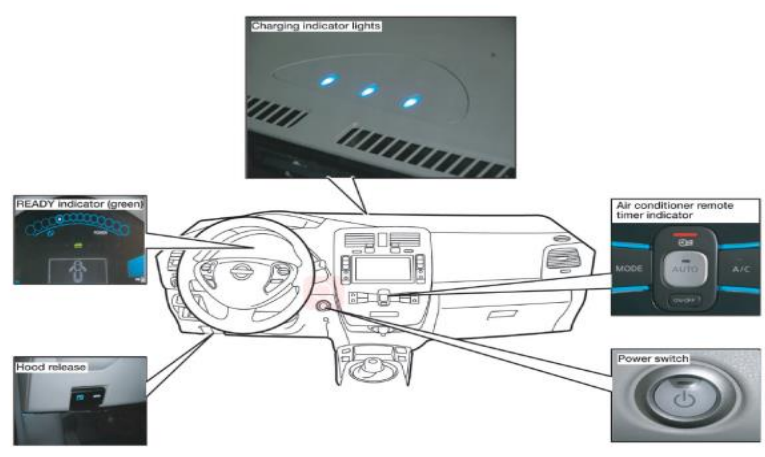

Figure.4. Related feature identification and components of Nissan LEAF new energy vehicle

\section{Forecast of Future Market Scale}

\subsection{Forecast of Inventory of New Energy Vehicles}

Based on the forecast results of experts that the proportion of sales volume of new energy vehicle market in 2020 , 2025,2030 and 2035 is $8 \%, 20 \%, 40 \%$ and $60 \%$ respectively, this study obtains the sales volume of new energy vehicle market in China from 2019 to 2035, as shown in the table below.

Table.2. Forecast of Sales Volume of New Energy Vehicles in China from 2019 to 2035

Unit: Ten thousand vehicles

\begin{tabular}{|c|c|c|c|c|c|c|}
\hline \multirow{2}{*}{ Year } & \multirow{2}{*}{$\begin{array}{c}\text { Sales volume of } \\
\text { traditional vehicle }\end{array}$} & \multicolumn{3}{|c|}{ Sales volume of new energy vehicle } & \multirow{2}{*}{$\begin{array}{c}\text { Sales volume } \\
\text { Total }\end{array}$} \\
\cline { 3 - 6 } & 1804.9 & 0.5 & 0.2 & 0 & 0.7 & 1806 \\
\hline 2010 & 1849.7 & 0.56 & 0.23 & 0 & 0.8 & 1850 \\
\hline 2011 & 1929 & 1.1 & 0.2 & 0 & 1.3 & 1930 \\
\hline 2012 & 2197 & 1 & 0 & 0 & 1.1 & 2198 \\
\hline 2013 & 2343 & 4 & 2 & 0 & 6.2 & 2349 \\
\hline 2014 & 2436 & 17 & 7 & 0 & 24.1 & 2460 \\
\hline 2015 & 2764 & 30 & 9 & 0 & 38.9 & 2803 \\
\hline 2016 & 2820 & 55 & 13 & 0 & 67.9 & 2888 \\
\hline 2017 & 2683 & 93 & 31 & 0 & 124.7 & 2808 \\
\hline 2018 & 2897 & 116 & 74 & 4 & 193.6 & 3091 \\
\hline $2019 \mathrm{~F}$ & 2926 & 153 & 98 & 8 & 259.0 & 3185 \\
\hline $2020 \mathrm{~F}$ & 2932 & 197 & 124 & 12 & 333.4 & 3266 \\
\hline $2021 \mathrm{~F}$ & 2920 & 247 & 153 & 16 & 416.7 & 3336 \\
\hline $2022 \mathrm{~F}$ & 2889 & 303 & 185 & 20 & 508.9 & 3398 \\
\hline $2023 \mathrm{~F}$ & 2842 & 366 & 220 & 25 & 610.0 & 3452 \\
\hline $2024 \mathrm{~F}$ & 2801 & 391 & 280 & 29 & 700.3 & 3502 \\
\hline $2025 \mathrm{~F}$ & 2708 & 509 & 297 & 34 & 839.8 & 3547 \\
\hline $2026 \mathrm{~F}$ & 2622 & 591 & 340 & 38 & 969.1 & 3591 \\
\hline $2027 \mathrm{~F}$ & 2526 & 679 & 387 & 43 & 1108.5 & 3634 \\
\hline $2028 \mathrm{~F}$ & & & & & & \\
\hline
\end{tabular}




\begin{tabular}{|l|l|l|l|l|l|l|}
\hline $2029 \mathrm{~F}$ & 2418 & 773 & 437 & 48 & 1258.4 & 3677 \\
\hline $2030 \mathrm{~F}$ & 2231 & 875 & 560 & 53 & 1487.6 & 3719 \\
\hline $2031 \mathrm{~F}$ & 2170 & 984 & 549 & 58 & 1590.3 & 3761 \\
\hline $2032 \mathrm{~F}$ & 2028 & 1099 & 610 & 63 & 1771.9 & 3800 \\
\hline $2033 \mathrm{~F}$ & 1872 & 1220 & 675 & 68 & 1962.7 & 3835 \\
\hline $2034 \mathrm{~F}$ & 1702 & 1346 & 742 & 73 & 2160.4 & 3863 \\
\hline $2035 \mathrm{~F}$ & 1551 & 1473 & 777 & 78 & 2327.0 & 3878 \\
\hline
\end{tabular}

Data source: Data from 2010 to 2018 is the data released by China Association of Automobile Manufacturers; Data from 2019 to 2035 is the forecast data of CATARC experts.

Take 8 years as the average scrapping time of new energy vehicles, add the annual sales volume of the period to estimate the annual inventory, and get the inventory information of new energy vehicles in China from 2019 to 2035 , as shown in the table and figure below. It is predicted that the proportion of new energy vehicles in the total number of vehicles will continue to rise. By 2020, 2025, 2030 and 2035, the inventory of new energy vehicles will reach 7.16 million, 31.47 million, 74.83 million and 136.67 million respectively.

Table.3. Forecast of Inventory of New Energy Vehicles in China from 2019 to 2035

Unit: Ten thousand vehicles

\begin{tabular}{|c|c|c|c|c|c|}
\hline Year & $\begin{array}{l}\text { Traditional } \\
\text { fuel vehicle }\end{array}$ & $\begin{array}{c}\text { New energy } \\
\text { inventory }\end{array}$ & $\begin{array}{c}\text { Wherein, } \\
\text { BEV }\end{array}$ & $\begin{array}{l}\text { Wherein, } \\
\text { PHEV }\end{array}$ & $\begin{array}{c}\text { Wherein, } \\
\text { FCEV }\end{array}$ \\
\hline 2010 & 9085 & 0.7 & 1 & 0 & 0 \\
\hline 2011 & 10577 & 1.5 & 1 & 0 & 0 \\
\hline 2012 & 12086 & 2.8 & 2 & 1 & 0 \\
\hline 2013 & 13696 & 3.9 & 3 & 1 & 0 \\
\hline 2014 & 15437 & 10.1 & 7 & 3 & 0 \\
\hline 2015 & 17176 & 34.1 & 24 & 10 & 0 \\
\hline 2016 & 19327 & 73.1 & 54 & 19 & 0 \\
\hline 2017 & 21559 & 141.0 & 109 & 32 & 0 \\
\hline 2018 & 23735 & 265.0 & 202 & 63 & 0 \\
\hline $2019 \mathrm{~F}$ & 25227 & 457.8 & 317 & 137 & 4 \\
\hline $2020 \mathrm{~F}$ & 26976 & 715.5 & 469 & 234 & 12 \\
\hline $2021 \mathrm{~F}$ & 28644 & 1047.7 & 665 & 358 & 24 \\
\hline $2022 \mathrm{~F}$ & 30070 & 1458.3 & 908 & 509 & 41 \\
\hline $2023 \mathrm{~F}$ & 31326 & 1943.1 & 1194 & 687 & 61 \\
\hline $2024 \mathrm{~F}$ & 32395 & 2514.2 & 1531 & 898 & 86 \\
\hline $2025 \mathrm{~F}$ & 33295 & 3146.6 & 1866 & 1165 & 115 \\
\hline $2026 \mathrm{~F}$ & 34001 & 3861.8 & 2282 & 1431 & 149 \\
\hline $2027 \mathrm{~F}$ & 34530 & 4637.3 & 2757 & 1697 & 183 \\
\hline $2028 \mathrm{~F}$ & 34862 & 5486.8 & 3282 & 1986 & 218 \\
\hline $2029 \mathrm{~F}$ & 34991 & 6411.8 & 3859 & 2299 & 254 \\
\hline $2030 \mathrm{~F}$ & 34842 & 7482.7 & 4487 & 2706 & 290 \\
\hline $2031 \mathrm{~F}$ & 34544 & 8564.1 & 5167 & 3069 & 328 \\
\hline $2032 \mathrm{~F}$ & 34022 & 9726.0 & 5901 & 3460 & 365 \\
\hline $2033 \mathrm{~F}$ & 33252 & 10988.4 & 6730 & 3854 & 404 \\
\hline $2034 \mathrm{~F}$ & 32269 & 12308.9 & 7567 & 4299 & 443 \\
\hline $2035 \mathrm{~F}$ & 31154 & 13666.8 & 8449 & 4736 & 482 \\
\hline
\end{tabular}

Data source: CATARC's forecast is based on the sales volume data released by China Association of Automobile Manufacturers. 


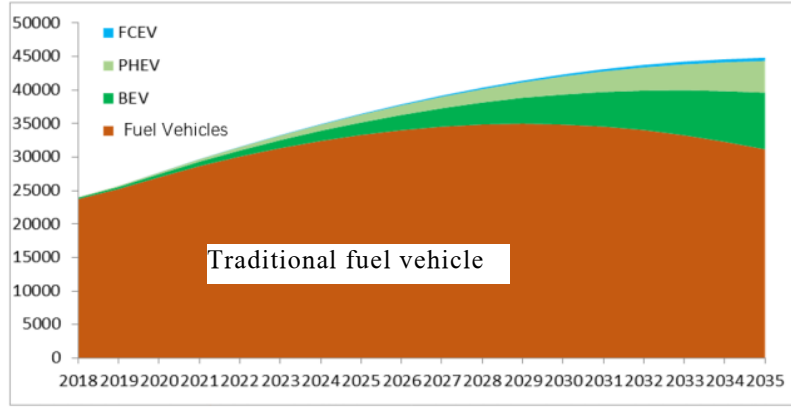

Figure.5. Forecast of Inventory Structure of New Energy Vehicles in China from 2019 to 2035

Data source: CATARC

\subsection{Market Forecast of End-of-life New Energy Vehicle}

At present, the proportion of waste vehicle recycling volume in the annual report of the vehicle market developed countries is $4 \%-6 \%$. On the basis of this data, considering the low residual value of the used battery electric vehicles, the scrap rate is usually higher than that of traditional fuel vehicles, and different scrap rates are set according to different models. The setting of scrap rate is shown in the table below.

Table.4. setting of proportion of scrap volume of new energy vehicles in the inventory in China

\begin{tabular}{|c|c|c|c|c|}
\hline Proportion & BEV & PHEV & FCEV & $\begin{array}{c}\text { Traditional } \\
\text { fuel vehicle }\end{array}$ \\
\hline $2019-2020$ & $3 \%$ & $2 \%$ & $2 \%$ & $2 \%$ \\
\hline $2021-2025$ & $4 \%$ & $3 \%$ & $3 \%$ & $3 \%$ \\
\hline $2026-2030$ & $5 \%$ & $4 \%$ & $4 \%$ & $4 \%$ \\
\hline $2031-2035$ & $6 \%$ & $5 \%$ & $5 \%$ & $5 \%$ \\
\hline
\end{tabular}

Based on the above settings, the scrap volume of new energy vehicles in China is predicted. By 2020, 2025, 2030 and 2035, the theoretical number of end-of-life new energy vehicles in China will be 190,000, 1,130,000, $3,440,000$ and 7,680,000 respectively. The theoretical number of end-of-life new energy vehicles from 2019 to 2035 is shown in the table below.

Table.5. Forecast of Theoretical Number of End-of-life New Energy Vehicles in China from 2019 to 2035

Unit: Ten thousand vehicles

\begin{tabular}{|c|c|c|c|c|c|}
\hline \multirow{2}{*}{ Year } & \multicolumn{2}{|c|}{$\begin{array}{c}\text { Forecast of theoretical scrap volume of } \\
\text { new energy vehicles by model }\end{array}$} & \multirow{2}{*}{ Total } & $\begin{array}{c}\text { Forecast of scrap } \\
\text { volume of traditional } \\
\text { fuel vehicles }\end{array}$ \\
\cline { 2 - 4 } & BEV & PHEV & FCEV & & 503 \\
\hline 2019 & 9.5 & 2.7 & 0.1 & 12.3 & 539 \\
\hline 2020 & 14.1 & 4.7 & 0.2 & 19.0 & 859 \\
\hline 2021 & 26.6 & 10.7 & 0.7 & 38.1 & 902 \\
\hline 2022 & 36.3 & 15.3 & 1.2 & 52.8 & 940 \\
\hline 2023 & 47.8 & 20.6 & 1.8 & 70.2 & 972 \\
\hline 2024 & 61.2 & 26.9 & 2.6 & 90.7 & 999 \\
\hline 2025 & 74.7 & 35.0 & 3.5 & 113.1 & 1360 \\
\hline 2026 & 114.1 & 57.2 & 6.0 & 177.3 & 1381 \\
\hline 2027 & 137.8 & 67.9 & 7.3 & 213.1 & 1394 \\
\hline 2028 & 164.1 & 79.5 & 8.7 & 252.3 & 1400 \\
\hline 2029 & 192.9 & 92.0 & 10.2 & 295.1 & 1394 \\
\hline 2030 & 224.3 & 108.2 & 11.6 & 344.2 & 1727 \\
\hline 2031 & 310.0 & 153.5 & 16.4 & 479.9 & 1701 \\
\hline 2032 & 354.0 & 173.0 & 18.3 & 545.3 & 1663 \\
\hline 2033 & 403.8 & 192.7 & 20.2 & 616.7 & 1613 \\
\hline 2034 & 454.0 & 215.0 & 22.1 & 691.1 & 1558 \\
\hline 2035 & 506.9 & 236.8 & 24.1 & 767.8 & \\
\hline
\end{tabular}

\section{Suggestions}

\subsection{Implement the responsibility of producers and drive the progress of dismantling level of end-of-life new energy vehicle.}

From the perspective of foreign countries, regardless of traditional fuel vehicles or new energy vehicles, automobile manufacturers are guiding the development of the industry, actively carrying out the guidance and promotion of recycling technology, formulating detailed dismantling manuals, and guiding the improvement of the industry's dismantling level from the aspects of environmental protection, safety protection, and improving the recycling rate, etc.. Therefore, it is suggested that China should speed up the implementation of the extended producer responsibility system, focusing 
on the guidance of dismantling enterprises in the form of publicly providing dismantling instruction manuals, so as to promote the technological level of the industry.

\subsection{Develop the industrial standards for technical requirements of dismantling of end-of-life new energy vehicles}

In view of the current situation that the recycling and dismantling technology of end-of-life new energy vehicles has not been popularized, the industrial standards for the technical requirements of recycling and dismantling of end-of-life new energy vehicles shall be studied and formulated as soon as possible, and scientific and reasonable specifications shall be prepared for the enterprise infrastructure, equipment, personnel, entry detection and classification, on-site transfer, safety protection, disassembly and storage of power battery, vehicle body dismantling process and other general technical requirements, etc., so that the whole industry can master the dismantling technology of end-of-life new energy vehicles as soon as possible.

\subsection{Pilot technology upgrading of end-of-life new energy vehicle enterprises in new energy vehicle promotion and application cities}

Compared with traditional vehicles, the scale of end-oflife new energy vehicles in China is still small, and enterprises need to invest capital, manpower and material resources to upgrade before they can recycle and dismantle end-of-life new energy vehicle. Therefore, not every enterprise is willing to carry out the business of recycling, dismantling and discarding the end-of-life new energy vehicles. At present, China's new energy vehicle scrapping demand is mainly concentrated in the cities with the largest number of new energy vehicles in promotion and application. Therefore, it is suggested to carry out the technology upgrading pilot of end-of-life new energy vehicle enterprises in these cities to make them have the dismantling capacities, so as to ensure that the end-of-life new energy vehicles appearing in batches can be recycled by enterprises. In the pilot process, industry organizations and research institutions are encouraged to guide enterprises to master dismantling technology through training and other ways, to have the ability of dismantling, and to encourage technical cooperation among enterprises.

\section{Acknowledgment}

This paper is supported by National Key Research and Development Program of China Solid Waste Resource Utilization Special Project -Automobile Products and Typical Parts Lifecycle Traceability System Design and Demonstration Application Research (2018YFC1902704).

\section{References}

1. Li Yi, Yu Dongxing, Zhang Shaoyu, et al. Study on the Fire Risk of Lithium-ion Batteries [J]. China Safety Science Journal, (2012), 22(11): 36 - 41.
2. WANG Qing-song, PING Ping, ZHAO Xue-juan, et al. Thermal runaway caused fire and explosion of lithium ion battery[J]. Journal of Power Sources,(2012), 208:210 - 224.

3. Technical Specifications for End-of-life Vehicles Recycling and Dismantling Enterprise (GB221282019),(2019)

4. XuJianfen, Tang Fangliang, RuanDongde. Discussion on Volatile Organic Substance Emission Control Standard of Vehicle Repair and Maintenance Company [J]. The Administration and Technique of Environmental Monitoring,(2012), 24(2): 1- 5. 